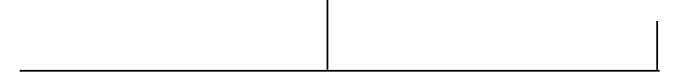

Rev. Latinoam. Psicopat. Fund., São Paulo, v. 12, n. 4, p. 533-635, dezembro 2009

\title{
Editorial
}

\section{Método clínico e conflito de interesses}

Manoel Tosta Berlinck

Há cerca de um ano fui admitido como membro da World Association of Medical Editors - WAME.

A WAME, criada em 1995, é uma associação voluntária internacional, sem fins lucrativos, de editores de revistas médicas que possuem corpo de consultores externos que avaliam e comentam os artigos por elas publicados. Trata-se de uma organização que busca promover a cooperação internacional e a educação de editores de revistas médicas.

Dentre as várias atividades da WAME (o leitor interessado pode acessar o portal http://www.wame.org), há um chatroom onde os editores conversam sobre suas dificuldades, hesitações, problemas, enfim.

Um dos temas mais frequentes nessas conversas é o conflito de interesses.

O que são conflitos de interesse?

Nenhuma atividade humana ocorre num ambiente neutro. Há sempre forças representando interesses que influenciam, modificam, inibem, estimulam qualquer atividade. 
Isso também ocorre na clínica em geral, e na clínica psicopatológica em particular, ou seja, a relação clínico-paciente é sempre intermediada por forças representando interesses que vão muito além do tratamento.

É sempre muito importante que o clínico reconheça as forças intervindo na relação com o paciente, principalmente as que modificam, desviam ou impedem o objetivo dessa relação: restabelecer um determinado estado, que pode ser chamado de saudável, no paciente. Essas forças constituem o que se denomina de "conflitos de interesse", pois possuem objetivos que competem com os da clínica.

A clínica psicopatológica, por sua vez, é aquela que leva à sério o significado da palavra psicopatologia, ou seja, discurso (logos) sobre o pathos psíquico. Pathos é palavra grega que, em sua complexidade semântica, aponta para "paixão", "passividade" e, por extensão, os afetos que constituem o paciente.

Este, quando procura um clínico, se apresenta, num primeiro momento, como um corpo perigoso, vale dizer, um corpo que, tendo necessidades, deseja, fala, fica doente e morre. O corpo perigoso que se apresenta ao clínico não está saudável, pois está sob o efeito de pathos, ou seja, é paciente.

Diante dessa delicada situação, o clínico se protege de diversas maneiras. Essas proteções proporcionam uma certa tranquilidade, mas também servem para desviar a atenção do clínico.

Quais seriam, então, essas forças que auxiliam o clínico e que, ao mesmo tempo, têm o poder de deslocar seu interesse afastando-o do paciente? São muitas e complexas e elas são, frequentemente, muito sutis. Tome-se, por exemplo, a própria noção de transtorno: diz-se que o paciente é portador de transtorno. É interessante observar, entretanto, que a palavra "transtorno", utilizada cada vez com mais frequência no meio clínico psicopatológico brasileiro, surgiu recentemente com as traduções do CID e do DSM para o português. Em inglês, a palavra utilizada é disorder e, segundo o dicionário Houaiss, "desordem" (tradução correta de disorder) abrange um campo semântico distinto.

A palavra "transtorno", segundo esse mesmo dicionário, possui três principais significados: 1 . situação que causa incômodo a outrem; contratempo; 2. situação imprevista e desfavorável, contrariedade, decepção; 3. leve perturbação orgânica.

Já a palavra "desordem" cobre, segundo o Houaiss, seis significados: 1. ausência de arrumação, de organização; 2. falta de lógica, incoerência, desvario; 3. falta de regularidade, desigualdade, desarmonia; 4. desarranjo resultante de má administração, de má gestão; 5. agitação, indisciplina; 6. tumulto, confusão, briga, conflito, sinônimo de disposição de ânimo. 
Percebe-se assim que, dependendo como o paciente é qualificado - portador de um transtorno ou de uma desordem - o procedimento clínico é determinado e orientado.

Mas a questão dos conflitos de interesse não termina aí. Ela surge, também, nos inúmeros recursos utilizados pelo clínico como, por exemplo, o enquadre, o sistema classificatório, a teoria, a ideologia, a filiação institucional etc.

Aquilo que pode ajudar o clínico na relação com o paciente pode, também, prejudicar essa mesma relação. Esta é uma das lições que podemos tirar dos conflitos de interesse.

\section{Manoel Tosta Berlinck}

Sociólogo; psicanalista; Ph.D. (Cornell University, Ithaca, N.Y., USA); professor aposentado da Universidade Estadual de Campinas - Unicamp (Campinas, SP, Brasil); professor do Departamento de Psicologia do Desenvolvimento da Faculdade de Ciências Humanas e da Saúde da Pontifícia Universidade Católica de São Paulo - PUC-SP (São Paulo, SP, Brasil); professor do Programa de Estudos Pós-Graduados em Psicologia Clínica da Faculdade de Ciências Humanas e da Saúde da Pontifícia Universidade Católica de São Paulo - PUC-SP, onde dirige, desde 1992, o Laboratório de Psicopatologia Fundamental; presidente da Associação Universitária de Pesquisa em Psicopatologia Fundamental - AUPPF (2002-2010); editor responsável de Pulsional Revista de Psicanálise e da Revista Latinoamericana de Psicopatologia Fundamental; membro da World Association of Medical Editors - WAME (Associação Mundial de Editores Médicos); diretor da Livraria Pulsional - Centro de Psicanálise e da Editora Escuta (São Paulo, SP, Brasil); autor de Psicopatologia Fundamental (2000) e de Erotomania, com German E. Berrios (2009), entre outros livros e numerosos artigos.

Rua Tupi, 397/103

01233-001 São Paulo, SP, Brasil

Telefax: (011) 3825-8573

e-mail: mtberlin@uol.com.br 